\title{
Mobile TV Broadcasting - What will be the Underlying Business Model in the Future?
}

\author{
Iwona Windekilde, Morten Falch \\ Center for Communication, Media and Information technologies \\ Copenhagen Institute of Technology, Aalborg University \\ Lautrupvang 15, DK-2750 Ballerup, Denmark \\ iwona@cmi.aau.dk \\ falch@cmi.aau.dk
}

\begin{abstract}
In most of the European countries, mobile $T V$ broadcasting market is in its infancy and mobile network operators, broadcasters, content providers and other players are still looking for the best business models. There are many opportunities for each player but there are also many threats which need to be overcome, depending on the particular business models and strategies each of them employs. This paper examines ongoing international trends in the mobile TV broadcasting market related to the various business models, new services offers and user preferences. The paper ends with a discussion on the future business models and factors that could influence a faster take up of mobile TV broadcasting.
\end{abstract}

\section{Introduction}

The aim of the paper is to study the major and emerging mobile TV markets and various factors that could add to the further take up of mobile TV. The paper discusses recent developments in the market for broadcast mobile TV services, focusing on the different business models and standards currently implemented in a number of markets.

Looking at the different mobile TV markets it is difficult to point out the most successful business. The future for mobile TV broadcasting market is uncertain for many players and no one can predict how this market will evolve and which business model will be the right one.

Players on the market need to resolve key issues, including content, pricing, user friendliness, business model, digital rights management and technology standards and spectrum allocation.

This paper discusses ongoing international trends in the mobile TV broadcasting market related to the various business models, new services offers and user preferences.
The paper is organized as follows. First section presents market developments in various countries. This includes business models, the number of users and technological solutions. In the next section, users preferences regarding content, use context, and willingness to pay are examined. In the following section, the new service offers are discussed. The paper ends with a discussion on the future business models and factors that could influence a faster take up of mobile TV broadcasting.

\section{Business models - country studies}

Various mobile broadcasting standards have been successfully launched in markets all over the world, e.g.: DVB-H, MediaFLO, ISDB-T, T-DMB, and SDMB.

Japan is a leading market for deployment of mobile TV services which are based on the ISDB-T (Integrated Services Digital Broadcasting) standard. In Japan mobile TV business model is embedded in broadcast infrastructure and mobile TV services are offer for free. All handsets are SIM-locked and produced according to the operator's specification. In fact, the operator pays the handset manufacturer for handsets ordered up front and markets them through its retail outlets itself, so manufacturers face much less risk in introducing new technologies. Until now Japan has shipped more than 20 million handsets equipped with TV receivers.

South Korea is the second fastest growing mobile TV market, with 10 million T-DMB devices. There are two competing mobile TV business models: a free-toair T-DMB service operated by 6 broadcasters and a competing S-DMB pay-service operated and marketed by the main mobile operator SK Telecom. The T-DMB in Korea has 17,24 million users and is strongly supported by the government. S-DMB pay-service has only 1,85 million users [4].

The Asian market, despite its large subscriber numbers has not been generated much revenue. This is 
due to free to air services offer, very restrictive regulation on advertising (in Korea), and broadcasting regulation which didn't permit special programming to mobile devices until 2008 (in Japan). Moreover it is difficult to estimate the exact number of the actual viewers in Japan and Korea because not everyone who has a mobile TV enabled device actually watches TV on it.

The U.S. has generally adopted the Forward Link Only (FLO) standard developed by Qualcomm. The FLO TV TM services are available on a subscription basis through two operators: AT\&T and Verizon Wireless. Even though mobile TV services have been offered since March 2007, it had fewer than 100.000 subscribers [7]. MediaFlo have recently acknowledged that mobile TV hasn't picked up the traction they'd expected and the growth in mobile TV users has been going slower than Qualcomm's MediaFlo would anticipate. Qualcomm put some blame on carriers, which hadn't spent a lot on advertising on it to this point. From the standpoint of innovative programs or innovative television techniques, there are no innovative programs. Both operators, Verizon Wireless and AT\&T offer the same programs as on traditional TV and have almost identical mobile TV offers regarding pricing (\$15 per month), channels (10) and handsets. The Open Mobile Video Coalition, group of more than 800 broadcaster hope to increase the number of mobile TV users in U.S. by implementing the new mobile DTV standard and offering mobile TV for free. The new Mobile DTV Standard provides the technical capabilities necessary for broadcasters' to provide new services to mobile and handheld devices using their digital television transmissions. ATSC (Advanced Television Systems Committee) Mobile DTV is being developed to support a variety of services including free (advertiser-supported) television and interactive services delivered in real-time, subscription-based TV, and file-based content download for playback at a later time. The standard may also be used for transmission of new data broadcasting services. The question is if there will be room for both standards nationwide, subscription based MediaFLO and individual local broadcasters in the mobile TV market in U.S.

Mobile operators across Europe are using, the DVB-H standard as recommended by European Commission. 3 Italy launched the world's first DVB$\mathrm{H}$ mobile TV service in 2006. Since the launch of new TV service, the subscriber count has grown to over 850,000 in October 2008. The business model in Italy have been based on the distribution of pay-tv packages: simulcast of existing traditional channels plus ad hoc content. Presently, there are two mobile broadcast networks in Italy: H3G network and Mediaset network. $\mathrm{H} 3 \mathrm{G}$ is pursuing a mobile network operator-led model managing its own MUX and service platform and keeping $85 \%$ of the revenues. TIM and Vodafone manage their own independent service platforms but rent network capacity from Mediaset network.

Recently (June, 2008), 3 Italia introduced free mobile TV services. Users have free access to some programs: RAI 1, RAI 2, Mediaset, SkyMeteo 24, Current TV and La3 while other channels as part of pay-TV offer. Users need a DVB-H receiver to watch programs. The introduction of the free mobile TV services is part of a new cross-media strategy to promote data services in Italy. The new services provided by 3Italia are able to be free because of the inclusion of interactive advertising.

In Finland, the DVB-H network licence has been granted to Digita in December 2006. The business model adopted in Finland is very flexible and open, allowing equal access to every actor involved. However, it has turned out that this model may lead to a lack of incentive for content providers as well as mobile network operators, which not even advertise the possibility for mobile users with DVB-H enabled terminals to get access to the free mobile TV channels. There is no information about how many people are using mobile TV because users do not need to subscribe for mobile TV services - they are offered for free. At the moment, no pay-TV channels are broadcasted.

In Austria, the DVB-H service was launched on the $30^{\text {th }}$ of May 2008. The media authority, KommAustria, awarded a license to MEDIA BROADCAST Gmbh Germany-based broadcasting network operator on February 29th, 2008. The business model implemented in Austria represents cooperative model (required by KommAustria) and promote partnership opportunities between the different players (content providers, network operators and content aggregators/service distributors). In the business model implemented in Austria, users can obtain a mobile TV package which contains DVB-H channels as well as TV programs available via the mobile data channel. Payment need to be made to Mobile Network Operators (MNOs). MNOs will then pay Media Broadcast and Pay TV channels. There is also a requirement that Media Broadcast need to provide public service channels for free. Mobile TV can in Austria only be accessed by users subscribing to the service. It is estimated that at the end of October 2008, 10.000 subscribers have used mobile TV services.

Among the European countries, only Germany have experienced a failure in the implementation of the DVB-H standard. The main reason for the failure of Mobile 3.0 consortium was the competing DVB-T standard. After the carriers failed to win the mobile TV license they were reluctant to carry handsets supporting 
the DVB-H network, and decided to release handsets which receive DVB-T transmissions free of charge. Therefore in 2008, Mobile 3.0 returned broadcasting licenses.

Table 1. Business models- summary

\begin{tabular}{|l|l|}
\hline Country|Standard & \multicolumn{1}{|c|}{ Business Model } \\
\hline FINLAND & $\begin{array}{l}\text { An open model with equal access } \\
\text { for all actors - free-to-air service } \\
\text { mecember 2006 }\end{array}$ \\
\hline $\begin{array}{l}\text { GERMANY } \\
\text { DMB, May 2006 } \\
\text { and was closed } \\
\text { mid 2008 }\end{array}$ & $\begin{array}{l}\text { The third-party mobile TV provider } \\
\text { model has not been successful in } \\
\text { Germany. In 2008, Mobile 3.0 } \\
\text { returned broadcasting licenses. }\end{array}$ \\
\hline $\begin{array}{l}\text { ITALY } \\
\text { DVB-H, }\end{array}$ & $\begin{array}{l}\text { Two different business models: } \\
\text { H3G network - represents } \\
\text { vertically integrated model with } \\
\text { free to air services offer. } \\
\text { Mediaset network - uses a much }\end{array}$ \\
less vertical integrated model \\
where Mediaset network rent a \\
network capacity to TIM and \\
Vodafon.
\end{tabular}

\section{User preferences}

Based on the research conducted in many countries, it can be pointed out that there are notable differences concerning users' preferences regarding mobile TV consumption, mobile device usage and attitudes towards new services.

Particular regional differences influence the rate of mobile TV adoption around the world, and these differences by necessity need to be considered by operators, broadcasters and manufacturers.

\subsection{Use context}

The commercial implementations of mobile broadcast TV services have shown that usage patterns differed from country to country. In Italy, almost $60 \%$ of the users watch mobile TV predominantly outdoors. Most users watch mobile TV in their professional environment: at work/school. In Austria more than $50 \%$ of the users are watching mobile TV at home [9]. Users are also likely to watch mobile TV when travelling on trains, buses and another form of public transportation. In countries such as South Korea and Japan, the expectation was that people would use mobile TV mostly outdoors, but homes, offices and the subway are as common as outdoor usage. It was surprising that in Korea, people are often watching mobile TV in their own cars $(18,3 \%)$. In Japan almost $40 \%$ of 1 -seg viewers are watching mobile broadcast $\mathrm{TV}$ at home/room with no TV.

\subsection{Content}

Particularly popular on mobile TV are sports, news and entertainment.

Sport is the leading content both in terms of penetration and viewing time. Users prefer watching live sport events over receiving only results. As an example, Italy launched their mobile TV services in time for the FIFA World Cup and had an astonishing take-up rate of 400.000 subscriptions in 10 months. Austria had mobile TV services available for the UEFA EURO 2008 Football Championship in June and at the end of October 2008 about 10.000 subscribers have been reached. In United States, viewer ship increases $103 \%$ over the daily average during U.S. Open Golf Championship playoff featuring Tiger Woods and Rocco Mediate. FLO TV's dedicated Olympics channel, available exclusively on AT\&T Mobile TV, was the most-watched channel on the AT\&T Mobile TV service during the live Olympics coverage.

Programs not designed especially for the mobile $\mathrm{TV}$, were found to be well received by mobile viewers in many countries, for example, in Austria the most popular channel was public free-TV channel ORF 1. A similar situation can be found in Finland, where the most popular was channel MTV3 and NELONEN, which are already popular choices on regular TV. In South Korea, the most popular content on both traditional and mobile media platform was drama and soap operas. 
It is expected that in the future a unique mobile TV content will be developed. In South Korea, one of the most successful programmes developed specifically for mobile TV was a dating game show. In China a madefor-mobile music show similar to The $\mathrm{X}$ Factor was very popular.

There is also a growing market for user-generated reality TV programmes, with interactive services such as See Me TV and YouTube.com, which allow users to upload and broadcast their own videos direct to the websites from their mobile devices and network with others who are interested in viewing these videos.

\subsection{Average use}

Market research and viewer usage data confirms that consumers are progressively adopting mobile TV services and, once adopted, using mobile TV services with increasing regularity. In South Korea and Italy, the average consumption of mobile TV is 64 minutes per day, which is higher than expected. In Austria viewing time is almost 30 minutes per day. Data presented by MediaFLO show that FLO TV viewers are spending an average of more than 20 minutes per day watching television on their phones. This is comparable to the average time U.S. cell phone users spend per day talking on their cell phones.

\subsection{Consumers willingness to pay}

Research conducted in Europe has shown that people are willing to pay a modest subscription fee for mobile TV, but it is more likely that the free-to-air model will be preferable for the fast take up by the users.

According to research conducted in Asia, customers are not willing to pay for services. $67 \%$ of $\mathrm{T}-\mathrm{DMB}$ users' answers said they will not use T-DMB if they have to pay for the service "Why they should pay for a program that is otherwise available for free?"

In Asia, the fast growth is also supported by users' preferences for buying new devices. According to the research, in Japan and Korea users are changing their devices every 10 months. Their predilections to new devices are well proved by the number of sold devices which are not only communication devices but also a status symbol and a fashion item in Asia.

\section{New services offer}

Broadcasted television needs to change from a mostly passive towards a more interactive medium in order to attract more viewers and to generate new source of revenue in the value chain.
Presently there is a huge growth of user generated contents mostly due to the widespread availability of video-enable devices and broadband connection. YouTube reported that users upload more than 75000 new videos per day and streams over 100 million videos daily back to users. According to comScore, $70 \%$ of the U.S. Internet audience views streaming video each month. Those changes present a new service paradigm for the transmission of popular user generated content from the Internet over mobile multimedia broadcasting networks.

TheBlogTV (Italy) plans to take advantage of these opportunities to create the first international user generated broadcasting network. TheBlogTV's unique selling proposition is the creation of a virtuous circle based on:

- The selection and involvement of each country's best vloggers, through interactive premium mechanism, to create user generated contents and programs

- The multiplatform distribution of contents, both on own channel and third party channels

- The direct collection of advertising revenues leveraging on cumulated audience [1].

BlogTV is a new form of social communication. The technology enables anybody with a web camera or a $3 \mathrm{G}$ phone to create their own TV show and broadcast it over the internet - live.

One of the new concepts of delivery new services and generating location-based advertising revenue is "Low-Power Service Model". This model has been designed to reduce the T-DMB transmitter's transmission power and provide services to limited areas, e.g. regions, market, shopping mall, and stadium. When viewers approach a particular commercial area, low-power services can effectively publicize the area and provide e.g. shopping information, commentary and related data to spectators in the stadium area, increasing their enjoyment accordingly. These specific uses can create diverse business models that meet the unique needs of the users, regional merchants' sponsorships, corporations, universities, and other operators. The infrastructure creation costs are low, and diverse application areas can be developed, thus contributing to the spread of mobile broadcasting.

Presently there are few examples of interactive programs:

- In Italy, 3 Italia has introduced Italian Innovative programs based on user-generated contents. This program is popular because fans are the program stars with opinions, curiosities, jokes, songs, fake commentary. 
- Rai Uno Mattina is video-participative program, broadcast daily on Rai. TV viewers can participate from home using a pc and a web-cam, a mobile or fixed-net video-phone. In the program, five viewers participate via their video-phones, interacting from main Italian cities, comparing and contrasting prices in markets.

- $\quad$ Alice Live Mash Up is a Video-participative TV. Viewers step in as interviewers and interact with the show's prestigious guests. At the beginning program was broadcast weekly Mondays at $7 \mathrm{pm}$. In 2007, the channel reached 24-hour transmission: its strong point became the production of live formats in prime time, which are brought to life through the contributions generated by users and their interaction via webcam.

\section{Conclusion}

Business models in different countries vary in several ways. But looking at the organizational setup and on payment flows, one can see a pattern of more or less vertically integrated models. The Finnish model is the most open and the model, that ' 3 ' in Italy stands for, is clearly the most closed (vertically integrated) model. Between these two extremes lie Mediaset in Italy and the Austrian model, where the Mediaset model, however, is a little more vertically integrated than the Austrian model. Different business models have been successfully introduced in different countries. An important lesson which can be learned from the German market is however, that it is essential to have support from key players in all parts of the value-chain in order to get a positive market response on mobile TV.

At present, it is difficult to predict how the best business model will look like. Both vertical integrated and more open models have been applied with success, and there is no doubt that cross industry collaboration will be crucial to create suitable revenue sharing arrangements between various players, e.g. content providers need revenue-sharing agreement to develop new, attractive content offer. Percentage to content providers influences availability of good content products (e.g. Japan's DoCoMo keeps 12\%, Italy's H3G keeps $85 \%$ of the revenues).

Research conducted in various countries has showed that payment for mobile TV services have a critical influence on the users' attitude towards adopting broadcast mobile TV. Free-to-air mobile TV services have been able to secure relatively high adoption rates in Japan and Korea.
In Europe and America, subscription business model dominate at the moment, but there is a tendency to also introduce free to air programs for subscribers. Recently, 3 Italia introduced free to air mobile services. In Austria, Media Broadcast is providing public service channels for free. In US, MediaFLO USA recently added a free-to-air promotional channel call PROMO, but for a limited time only.

Until now it seems that a good approach for mobile operators is to start with a free-to-air business model which also involves minimum capital investment. Once user uptake of services starts to grow, operators can then think of developing new revenue models that can be established on top the free-to-air content platform.

Advertising will undoubtedly play an important role in mobile TV market but will require more creative forms of advertising than on traditional TV, e.g., product placement, dedicated channels (which depends on the availability of bandwidth) or new form of advertising like localization based services which receive some attention particularly in Korea and among broadcasting companies in U.S.

If mobile broadcast TV services will not gain the sustained level of uptake, advertisers will not be interested in mobile TV market.

To make mobile TV successful a combination of free to air offer, variety of attractive and cheap devices and a new programming paradigm based on interactive services offer and on personalization experience is crucial.

\section{References}

[1] R. V. Ducey, M. R. Fratrik, J. S. Kraemer, Broadcasters' competitive advantages in the mobile video marketplace, July 29,2008

[2] Mobile Broadcast Business Models, Country-specific Implementations, BMCO Forum, February 2009

[3] M. Falch, A. Fleury, I. Windekilde, State of the art Country studies, Converged Advanced Mobile Media Platform, Deliverable D 4.1., February 2009

[4] Y.H. Kim, T-DMB and its Convergence with Telecommunication, University of Seoul, Next-Generation Digital Broadcasting Standards Forum (NGBF)

[5] Sustainable Economic of Mobile TV services, 2nd white paper, UMTS/GSM Work Group, Jan 2008.

[6] S. Kim, Korean Lessons from deployment of Mobile TV, Media Economics Research Team, ETRI, December 2008.

[7] MediaFlo, Creating a Mobile Broadcast Platform, The MediaFLO $^{\text {TM }}$ System Product Overview, 2008

[8] T-DMB White Paper, ETRI, Korea, p.16

[9] A. Berger, DVB-H in Austria, Telecommunications Research Center Vienna, November 2008. 